\title{
The Impact of COVID-19 on Tourist Satisfaction with B\&B in Zhejiang, China: An Importance-Performance Analysis
}

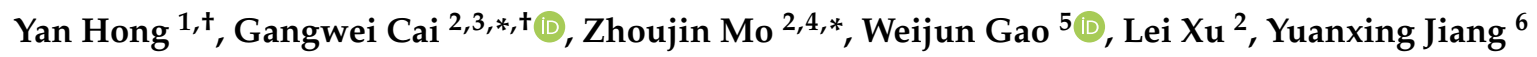 \\ and Jinming Jiang ${ }^{5}$ \\ 1 School of Civil Engineering and Architecture, Zhejiang Sci-Tech University, Hangzhou 310018, China; \\ hy@zstu.edu.cn \\ 2 College of Civil Engineering and Architecture, Zhejiang University, Hangzhou 310058, China; \\ xulei8563@zju.edu.cn \\ 3 Zhejiang Province-Subordinate Architectural Design Institute, Hangzhou 310058, China \\ 4 The Architectural Design \& Research Institute of Zhejiang University Co, Ltd., Hangzhou 310014, China \\ 5 Faculty of Environmental Engineering, University of Kitakyushu, Fukuoka 8080135, Japan; \\ gaoweijun@me.com (W.G.); jjmwolf@outlook.com (J.J.) \\ 6 Zhejiang Tongji Vocational College of Science and Technology, Hangzhou 311231, China; \\ jiang_yuanxing@126.com \\ * Correspondence: 11712014@zju.edu.cn (G.C.); mozj1979@126.com (Z.M.) \\ + These authors contributed equally to this work.
}

Received: 13 May 2020; Accepted: 22 May 2020; Published: 25 May 2020

Abstract: After the outbreak of COVID-19 (especially in the stage of tourism recovery), the bed and breakfast $(B \& B)$ tourism industry faced big challenges in improving its health strategies. B\&Bs are very important for the tourism industry in China and many other countries. However, few studies have studied the impact of B\&Bs, under COVID-19, on tourism in China. Our paper is among one of the first studies to investigate the impact of COVID-19 on tourist satisfaction with B\&Bs in China. The work/travel restrictions started from 20 January 2020, and work/after travel resumed from 20 February 2020 in Zhejiang, China. Data were collected from 588 tourists (who experienced B\&Bs in Zhejiang, China) from a WeChat online survey, from 1 March to 15 March 2020. The current study attempted to fill the gap by studying the changing tourist satisfaction levels with B\&Bs before/after COVID-19. Moreover, some suggestions are given to the $B \& B$ industry for tourism resumption after COVID-19 by an importance-performance analysis (IPA).

Keywords: tourist satisfaction; importance-performance analysis (IPA); COVID-19; bed and breakfast (B\&B); tourism resumption

\section{Introduction}

Corona virus disease 2019 (COVID-19) is a highly infectious disease with a long incubation period [1]. It is the latest infectious disease to rapidly develop worldwide [2]. Twenty-seven cases of the unknown virus were reported on 31 December 2019 [3]. An estimated 60 million residents of Wuhan and many other cities in China were subjected to community containment measures from 23 January 2020. These large-scale types of actions have never been used in the past (even for SARS in China) [4].

One of the important goals is to minimize the economic impact of the virus on a global scale [5]. China, as the world's most populous nation and the world's second-largest economy, had already battled with an epidemic (SARS); at the time, however, it was $4 \%$ of the global total-it is now $17 \%$ [6]. 
Consumption during the first season in China will be greatly reduced: tourism (e.g., bed and breakfast (B\&B)), hotels, catering, entertainment, and other traditional living service industries have suffered the most [7]. Work resumption in China was raised step by step from 20 February 2020 [8].

In 2003, a window of opportunity to modify tourism development was opened by the crisis of SARS [8]. Nature-based areas (e.g., B\&Bs in the countryside) were likely to be the target destinations $[9,10]$. New motivations to travel to nature-based areas became evident with SARS [11]. There was a potential marketing emphasis that nature-based tourism types (e.g., nature-based B\&Bs) could be invigorated and expanded after the COVID-19 crisis [12].

Thus, this article focuses on B\&Bs in Zhejiang, China. There are two reasons for this: (1) the COVID-19 epidemic improved in Zhejiang. From 23 January to 1 April, 2020, there was only one death in Zhejiang. No medical staff were infected. There were also no new confirmed cases from the residents for more than 14 consecutive days. Zhejiang resumed work gradually from 20 February 2020 [13]. (2) According to a B\&B market development report in 2019, the main force of the B\&B was from Zhejiang [14].

The COVID-19 epidemic has been reported in many previous papers. Some researchers have reported the impact of COVID-19 on mental health in China $[15,16]$. However, few studies have reported the impact of the bed and breakfast (B\&B) industry, under COVID-19, on tourism in China, even though it has severely affected China and the rest of the world. B\&Bs were very important for the tourism industry in China and many other countries and were especially welcomed by tourists in China, United States, and other countries $[17,18]$. Our paper is among one of the first studies to investigate the impact of COVID-19 on tourist satisfaction with B\&B in China. The time before/after satisfaction was before the work/travel restrictions (from 20 January 2020) until work/after travel resumption (after 20 February 2020). Data were collected from 588 tourists (who have experienced B\&Bs in Zhejiang, China) from a WeChat online survey, lasting from 1 March to 15 March 2020. The adjusted importance (after COVID-19)-performance (before COVID-19) analysis (IPA) was used. The current study attempts to fill the research gap by investigating the changes in tourist satisfaction levels with B\&Bs before/after COVID-19. Moreover, some suggestions are given to the B\&B industry to recover after the COVID-19 crisis by an importance-performance analysis (IPA).

Figure 1 shows the logical model. First, this study was carried out to measure the intervening influence of B\&Bs before/after COVID-19 on the correlations with tourist satisfaction levels in Zhejiang, China $[19,20]$. There were 588 responses that were selected (who have experienced B\&B in Zhejiang, China) for the analysis. Second, descriptive statistics and an importance-performance analysis (IPA) were used to measure the impact of B\&B before/after COVID-19 on tourist satisfaction levels in Zhejiang. IPA is a business research technique developed as a market tool to examine and suggest management strategies [21]. IPA prioritizes management suggestions regarding the optimal allocations that should improve tourist satisfaction. Thus, it could be a valuable practical tool for management decisions [22]. Third, some suggestions are given to the B\&B industry to recover after the COVID-19 crisis by an importance-performance analysis (IPA). Moreover, suggestions of crisis preparedness and disaster-management strategies for future research are given [23]. The purpose of this article was to help the B\&B industry to adapt to resumption after the COVID-19 crisis.

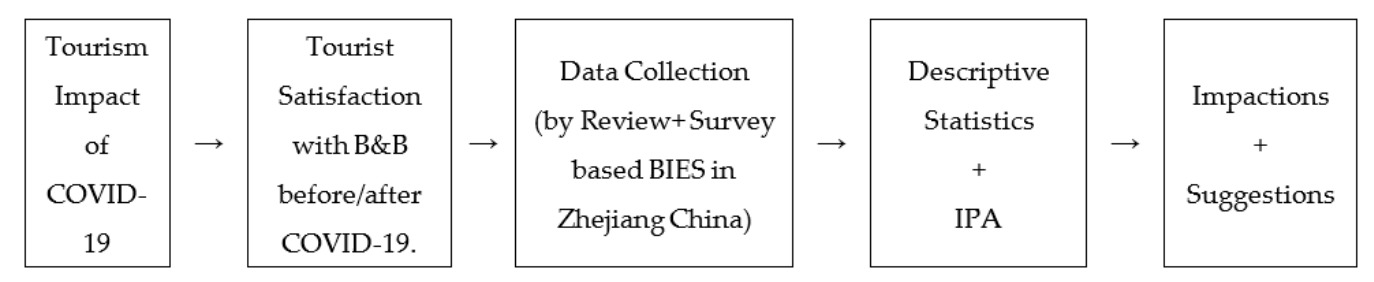

Figure 1. The logical model. Notes: $B \& B=$ Bed and Breakfast, $B I E S=B \quad \&$ B industry evaluation standard, COVID-19 = Corona Virus Disease 2019, IPA = importance-performance analysis, IA = Importance (After COVID-19), PB = Performance (Before COVID-19), QN = Question Number, TS $=$ tourist satisfaction . 
This article contains six sections. Section 1 is the introduction. Section 2 contains a literature review. Section 3 contains data collection and research methods. Section 4 contains the results. Section 5 comprises the impacts and limitations. Section 6 contains the conclusions.

\section{Literature Review}

\subsection{Crisis (e.g., SARS and COVID-19) Impact on Chinese Tourism and BEB}

First, natural disasters and anthropogenic environmental problems [24,25], as well as their potential to affect the image of destinations, have impacts on travel and tourism on various scales $[26,27]$. According to world tourism organization (WTO), in 2003, tourism arrivals fell by $1.2 \%$ to 694 million (compared to the same period in 2002) in China, and hotel occupancy rates fell by 10\% [28].

Second, the number of tourists increased by $9.2 \%$ (the first two months of 2003) over the same period in 2002, and tourism revenue increased by $14.0 \%$. After the outbreak of SARS, the number of tourists in March 2003 decreased by $6.5 \%$, as compared to the same period in 2002. See in Figure 2 the first monthly decrease in past decades [12].

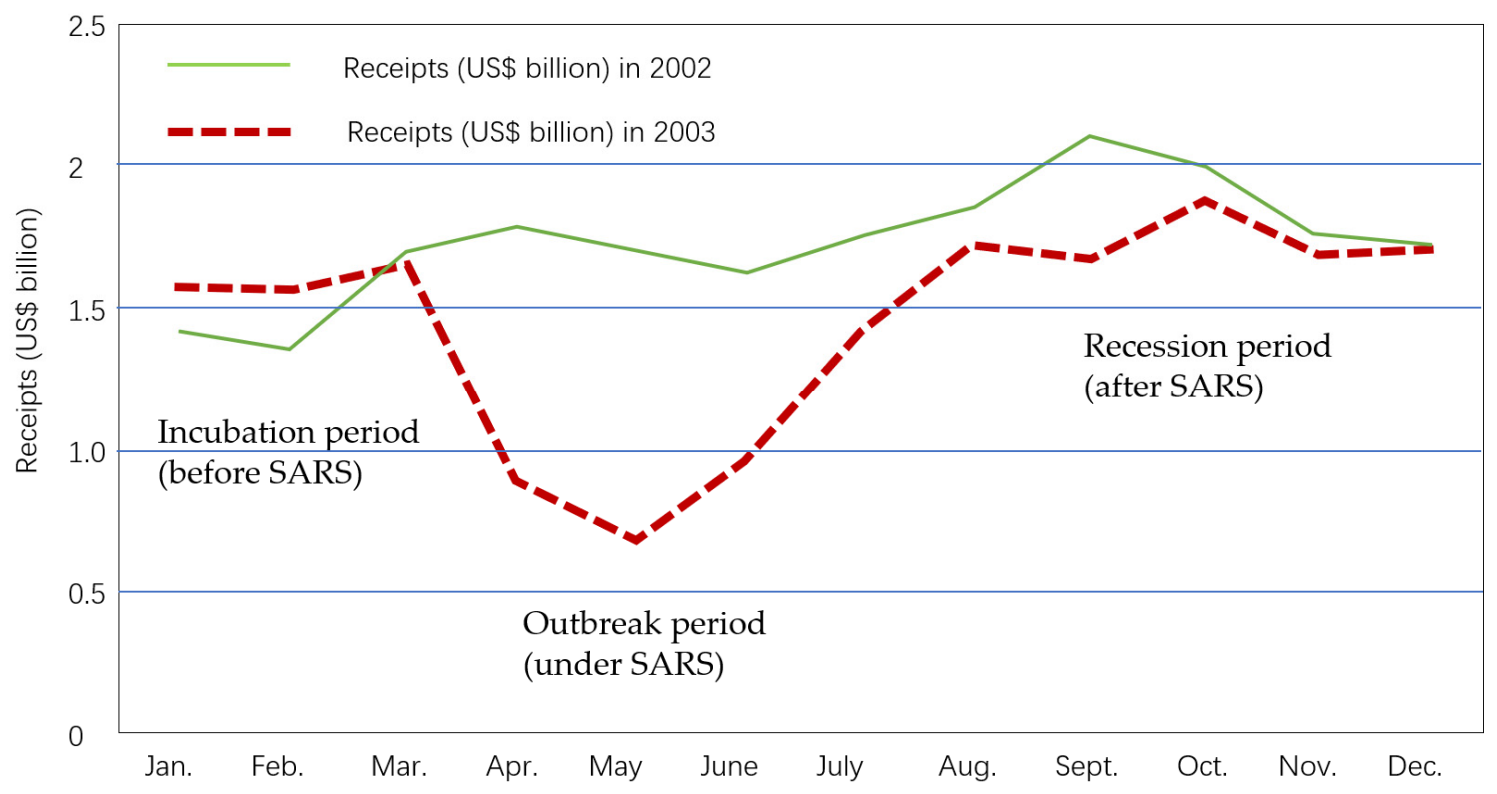

Figure 2. The impact of SARS on Chinese tourism between 2002 and 2003 [12].

Third, how long does it take to repair the impacts of an infectious disease on tourism? The development of the crisis' events can be divided into three periods, according to the impact on tourist flow, including the incubation period, outbreak period, and recession period. The impact time of most crisis events is within one year; the impact period of a few events was around two years. Taking SARS as an example, the peak period of impact was from March to June 2003, and the entire impact period was about 1 year [12]. Taking the accommodation industry as an example, during 2003, single-store revenue of in high-star hotels declined significantly. B\&B grew by $15.2 \%$ in 2003 and continued to grow, resulting in a $22 \%$ growth in 2004 . Therefore, the impact of SARS on B\&Bs in tourism was basically eliminated about half a year after the end of SARS [28].

\subsection{Tourism Resumption Post-Crisis (e.g., SARS and COVID-19)}

First, the destination image is defined as an individual's mental representation and overall perception of a particular destination [29]. Destination image and tourist satisfaction are also important tools to actively research and manage the perceptions of tourists about the destination [30,31]. The key of the before/after crisis themes that emerged included a lack of disaster-management plans, damage to destination image and reputation. It also included the changes in tourist behavior during the crisis 
(e.g., COVID-19) [23]. To influence the destination choice decision-making process and to condition the after-decision-making behaviors, including participation [32], satisfaction, and future intention (e.g., sustainable mountain tourism [33,34]) to revisit [35]. The destination image is generally interpreted as impressions based on information processing from various sources over time that results in a mental representation of the attributes and benefits sought in a destination [36].

Second, our focus on post-crisis recovery is required because much of the research relates to tourism crisis (e.g., COVID-19) management [37]. The recovery should be taken as more than just an industry or economic approach, and should focus on pre-event levels [38-40]. The importance of the relationship between marketing with tourist satisfaction and suggestions to repair destination images was identified [23].

\subsection{The Concept of $B \mathcal{E} B$}

First of all, apart from hotels and guesthouses, the most common form of accommodation is bed and breakfasts (B\&Bs), which is a concept that originated in Europe [41]. These refer to small hotels that provide a non-commercial, home-like environment and only serve breakfast [41]. This also means that visitors or guests pay to stay in a private residence and interact with a local family [42]. B\&Bs allow tourists to seek lodging for the night, especially when hotels and inns are unavailable in remote areas [43]. Second, the basic standards are different from other types of hotels are. The differences include B\&Bs being small scale, family operated and providing special services [44]. In recent years, the $B \& B$ industry has become a unique and rapidly growing industry in the hotel industry [45]. This operation attracts tourists with different standards than hotels [46].

\subsection{BEB in Zhejiang}

This study was carried out in Zhejiang, China. As the most popular B\&B rural tourist destination in China, the area receives more than 23.52 million tourists. From 1 January 2015, to 14 December 2019, the Baidu index results showed that the top 10 B\&B provinces and cities were Zhejiang, Guangdong, Sichuan, Jiangsu, Beijing, Shanghai, Shandong, Henan, Chongqing, and Hubei. It shows that Zhejiang was the most concerned about B\&Bs. Most of these areas are economically developed provinces and cities. According to the B\&B Market Development Report in 2019, the main force of the B\&B was from Zhejiang Province and accounts for about $60 \%$ of tourists, which is consistent with the search results of the area where B\&Bs are present [47]. The highest media coverage about B\&Bs in China was in Zhejiang from January 2015 to February 2018. The topics of media concern ranged from the rapid development of $B \& B$ s and the reference of $B \& B$ experience to the problems arising in the development of $B \& B$ s and lasted until the introduction of $B \& B$ standards, which indicates that the development of $B \& B s$ in China entered a stable development stage from the initial stage of rapid growth without supervision [47].

\subsection{Tourist Satisfaction}

Various definitions of satisfaction have been proposed in the literature. In the tourism sector, tourist satisfaction (TS) is an essential aspect of the tourist services sector [48]. As services directly impact people [49], some researchers have indicated that services are linked to tourist satisfaction [41]. Tourist satisfaction, as a marketing tool, plays a key role in the construction of strategies in the tourism market [50]. Furthermore, satisfaction is vital for successful destination marketing [51], as well as a service organization [52]. Feelings of pleasure by tourists are a sign of satisfaction [53], while tourists who enjoy visiting are satisfied [54,55]. Therefore, tourist contentment is a considerable factor for tourists in making up their minds to visit again or not [56-58].

Enhancing tourist satisfaction is a key strategy that leads to the success of companies in the hotel [59,60], catering [61,62], and tourism industries [63]. The quantitative approach with surveys was extensively adopted by scholars to study the multiple determinants of tourist satisfaction [64]. For instance, Deng et al. [65] surveyed 412 overseas tourists in Taiwan and found tourist complaints and 
service quality were related to tourist satisfaction. Kim et al. [66] gathered the opinions of 317 tourists from Beijing and discovered that convenience, safety, and technological inclination were the main factors that influenced tourist satisfaction. As a unique style of accommodation, it was inappropriate to employ the factors identified in other contexts directly to B\&B during our investigations [67-69].

\section{Materials and Methods}

\subsection{Data Collection}

\subsubsection{Explanation of Questionnaire}

This study was carried out to measure the intervening influence of B\&Bs before/after COVID-19 on its relationship with tourist satisfaction in Zhejiang, China. We used WeChat (Tencent, Shenzhen, China) for this online survey in Zhejiang, China. We received 1120 answers to the questionnaire. However, there were 588 responses from people who have experienced B\&Bs in Zhejiang before the COVID-19 that were selected for the analysis. The responses were collected from 1 March to 15 March 2020.

The questionnaire consisted of 30 factors, from the expectation of B\&Bs before check-in, to the perception of facilities after check-in [70]. Likert's five-point scale was used to measure tourists' expectations before check-in, with five optional levels [71]: (1) Importance (After COVID-19): " $5=$ very important", " $4=$ important", " $3=$ so-so", " $2=$ unimportant", and " $1=$ very unimportant". Appendix A shows the sample questionnaire [72,73]. (2) Performance (Before COVID-19): " 5 = very good", " 4 = good", " 3 = so-so", " $2=$ not good", and " 1 = bad".

\subsubsection{Questionnaire Items}

In addition to people's natural awareness and sharing awareness, the development of home-stays is more about providing experiential services for tourists than those provided by basic accommodation services [74]. Some researchers constructed an experiential scale to tap into tourist experiences in the accommodation industry $[75,76]$. The determinants of consumer satisfaction with B\&B establishments were studied and a hierarchical structure of these determinants was built. Thus, with the intention of bridging this gap, we aspired to develop a multiple-item scale to measure tourist opinions about B\&Bs before/after COVID-19.

Ten determinants of tourist satisfaction were identified [77]. Based on previous research and B\&B industry evaluation standards (BIES) in China (Table 1, Figure 3), a number of factors were generated. All the factors were assessed for content and face validity by a panel of experts from two institutions affiliated with the authors [78,79].

\begin{tabular}{|c|c|c|c|c|}
\hline $\begin{array}{l}118 \text { determinants of } B \& B \text { industry } \\
\text { evaluation standard (BIES) in China } \\
\text { [63] }\end{array}$ & \multirow{3}{*}{$\rightarrow$} & \multirow{3}{*}{$\begin{array}{l}\text { Review }+ \text { Survey } \\
\text { (based on Zhejiang } \\
\text { Industry } \\
\text { Association) }\end{array}$} & \multirow{3}{*}{$\rightarrow$} & \multirow{3}{*}{$\begin{array}{l}30 \text { factors (the closest to the } \\
\text { influence of COVID-19) of } \\
\text { tourist satisfaction with B\&B } \\
\text { importance (after COVID- } \\
\text { 19)/performance (before } \\
\text { COVID-19) }\end{array}$} \\
\hline+ & & & & \\
\hline $\begin{array}{l}10 \text { determinants of tourist } \\
\text { satisfaction to ward } B \& B \text { (based on } \\
\text { previous research) }\end{array}$ & & & & \\
\hline
\end{tabular}

Figure 3. Logic of selection of the 30 questionnaire factors. 
Table 1. The 30 items to measure B\&B experience before/after COVID-19.

\begin{tabular}{|c|c|c|}
\hline $\begin{array}{c}\text { Determinants of Tourist } \\
\text { Satisfaction to Ward B\&B } \\
\text { (Based on Previous Research) }\end{array}$ & 30 Factors: Importance (after COVID-19)/ Performance (before COVID-19) & QN \\
\hline B\&B Location $[18,43,77]$ & Location and nearby facilities are safe and good. & 1 \\
\hline \multirow{6}{*}{ Facility Quality $[18,43,77]$} & The kitchen and dining room are clean and tidy. & 2 \\
\hline & The leisure area is clean and tidy. & 3 \\
\hline & Other service rooms are clean and tidy. & 4 \\
\hline & Buildings are intelligent (e.g., semi-self-service management). & 5 \\
\hline & Places or items for cleaning and disinfection are provided to tourists. & 6 \\
\hline & The building is safe and reliable. & 7 \\
\hline \multirow{8}{*}{ Room Quality $[18,43,77]$} & The emergency facilities are complete (such as: first aid kit, escape equipment). & 8 \\
\hline & The shading performance is good (e.g., opaque curtains). & 9 \\
\hline & The rooms have plenty of natural light. & 10 \\
\hline & Split air conditioners are used in guest rooms. & 11 \\
\hline & Rooms are naturally ventilated. & 12 \\
\hline & The rooms are spacious and clean. & 13 \\
\hline & The natural landscape outside the window is good. & 14 \\
\hline & The privacy of rooms is good. & 15 \\
\hline \multirow{2}{*}{ Service Quality $[80,81]$} & Contingency plans are developed and can be exercised regularly. & 16 \\
\hline & $\begin{array}{c}\text { Green consumption is encouraged and environmental protection measures are } \\
\text { implemented. }\end{array}$ & 17 \\
\hline \multirow{6}{*}{ Specialties $[77,82]$} & $\begin{array}{l}\text { The indoor and outdoor transition spaces are natural and beautiful (e.g., gallery } \\
\text { frames, awnings, balconies). }\end{array}$ & 18 \\
\hline & The outdoor space is large and natural (e.g., courtyard, terrace, roof garden). & 19 \\
\hline & The proportion of public space is large. & 20 \\
\hline & The layout of the rooms is scattered. & 21 \\
\hline & Rooms of Single B\&B are few and exquisite. & 22 \\
\hline & The local culture is attractive. & 23 \\
\hline \multirow{2}{*}{ Surrounding Environment [83] } & The local people around the $B \& B$ are kind. & 24 \\
\hline & The environment around the $B \& B$ is rural and natural. & 25 \\
\hline \multirow{2}{*}{ Consumption Emotion $[84,85]$} & The B \& B atmosphere is good (e.g., leisurely, warm). & 26 \\
\hline & The experience and interaction in the space is good. & 27 \\
\hline Expectation Fulfillment [86] & B\&B matches the expectations. & 28 \\
\hline Perceived Value [87] & $\mathrm{B} \& \mathrm{~B}$ is an important part of travel. & 29 \\
\hline Satisfaction $[88,89]$ & Satisfaction with the B\&B. & 30 \\
\hline
\end{tabular}

Note: IA = Importance (After COVID-19), PB = Performance (Before COVID-19), QN = Question Number.

\subsection{Importance-Performance Analysis (IPA)}

\subsubsection{Concept of IPA}

Importance-Performance Analysis (IPA) is a business research technique developed as a marketing tool to review and suggest new management strategies [21]. While it was originally developed for marketing purposes, its applications have expanded to various fields, including tourism [90-92], healthcare [93,94], sustainable cities [95], social and economic outcomes [96,97], etc. The main goal of IPA is to diagnose the performance of different product or service attributes while facilitating data interpretation and providing practical recommendations for management [98]. IPA can gain insight into which product or service area managers should be targeted by identifying the most critical attributes, strengths and weaknesses [99]. The IPA technique combines measures of tourists' perceived performance and importance into a two-dimensional plot to facilitate data interpretation [21]. Thus, each quadrant in the standard IPA chart represents a different strategy that can help managers to identify areas of concern and necessary measures to increase tourist satisfaction [100]. Choosing the right attributes to measure importance and performance is essential for obtaining the best management decisions because these decisions rely on the information revealed from the selected attribute set [101]. Figure 4 shows the IPA model. 


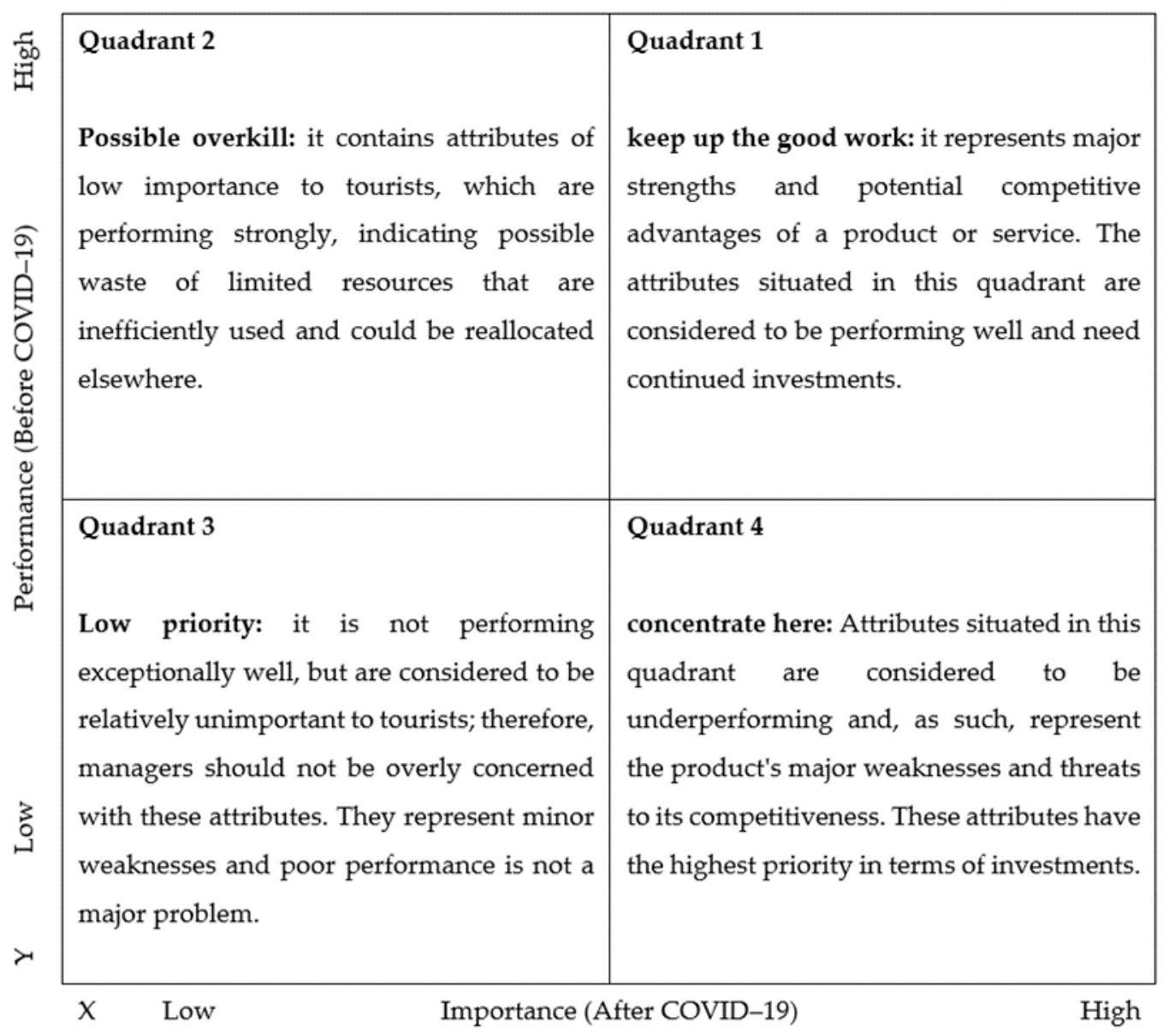

Figure 4. The importance-performance analysis model. Note: IA = Importance (After COVID-19), $\mathrm{PB}=$ Performance (Before COVID-19).

\subsubsection{Location of the Discriminating Thresholds within the IPA Plot}

The best place to divide the graph into quadrant thresholds is one of the biggest problems in IPA applications [102]. The choice of threshold is almost a matter of judgment $[103,104]$. However, their subjective positions has led to inconsistencies in existing IPA research results [104].

First, the data-centric (DC) method uses the actual data average of the observed importance and performance level as the critical point. Therefore, scholars have proposed another solution [105-107]. That is, they set the mean of the experience gained from the data as the intersection [108].

Second, some authors suggested that the SC method is more transparent when interpreting research results and usually provides a simpler description than using actual data methods [104]. However, using the scaling method has a serious drawback, that is, in addition to the fact that it is not driven by actual data, it also tends to record the high importance level of all the attributes. The latter means that, regardless of the characteristics of the interviewees, it turns out that this is the determinant of their expectations and opinions [109]. Each survey will have the same discrimination threshold. Incorrect threshold settings may lead to misleading and conflicting management recommendations [22].

Third, other researchers used diagonal lines (DL) or so-called isolines (IRL) to divide the plot into two separate areas [103]. The point on this $45^{\circ}$ upward line indicates an attribute with the same importance and performance level; compared to the subjective threshold selection method, the IRL method can be said to be a more suitable method for identifying the area of interest because it directly focuses on satisfaction and importance grade difference [22]. Rial et al. [110] simplified this method by empirical means and a diagonal line with discrepancies. The difference in attributes (distance from the diagonal) is considered to be a priority in improving the service [108]. 
Linear relationship (or linear association) is a statistical term used to describe the linear relationship between variables and constants. Mathematically speaking, the linear relationship satisfies the equation:

$$
y=m x+b
$$

In this equation, " $x$ " and " $y$ " are the two variables associated with parameters " $m$ " and " $b$ ". Graphically, $y=m x+b$ is drawn on the $x$ - $y$ plane with the slope " $m$ " and $y$-intercept " $b$ ". When $x=0$, $y$-intercept " $b$ " is just the value of " $y$ ". Calculate the slope " $m$ " from any two separate points $(x 1, y 1)$ and $(x 2, y 2)$, as follows:

$$
m=(x 2-x 1) /(y 2-y 1) .
$$

However, compared to the standard IPA chart (with four quadrants), it produces less information, provides limited identification ability and therefore has limited interpretation ability. Therefore, it limits the usefulness of IPA [22].

The actual means of importance and performance are likely to differ in most cases, and therefore, require study-specific adjustments to the scales in order to interpret the importance and performance ratings [111], as well as the relative interpretation of attributes within the importance and performance ratings [22]. Most researchers use DC and average values of the actual importance and performance level when determining the threshold value of tourism research [108]. IRL directly focuses on differences in satisfaction (Before COVID-19) and importance (After COVID-19) ratings. Therefore, this article uses the method of DC+IRL when specifying the thresholds of the impact before/after COVID-19 on tourist satisfaction with B\&B (Figure 5).

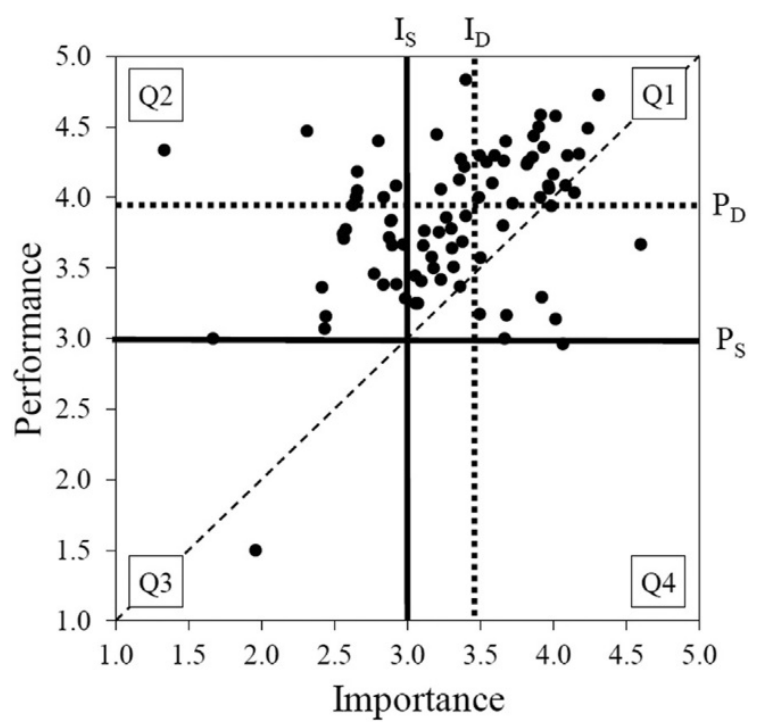

Figure 5. The line of different thresholds within the IPA plot. Note: Graphical comparison of scale-centered (IS - PS) and data-centered (ID - PD) approaches [22] in identifying the IPA quadrants.

\section{Results}

\subsection{The Descriptive Statistics}

\subsubsection{Profile of Survey Respondents}

Table 1 describes the respondents' demographic profile [96-98]. Among the 588 tourists, 55.78\% were women and $44.22 \%$ were men. The majority of the participants ranged from 25 to 35 , accounting for $45.92 \%$ of the samples. Most of the respondents had a bachelor or graduate degree $(51.02 \%, n=300)$, followed by graduate degrees $(32.31 \%, n=190)$. With regards to monthly income, $45.92 \%(n=270)$ reported that their annual income was between $\$ 801$ and $\$ 1200$. 


\subsubsection{Reliability and Validity Analysis}

The statistical software of SPSS 26 (IBM, New York, NY, USA) was used in the questionnaire analysis [112,113]. The calculation of the questionnaire's reliability was based on the Cronbach's Alpha coefficient [101,102]. An $\alpha$ larger than 0.7 indicates "highly reliable" and larger than 0.5 "reliable" [114-116]. The $\alpha$ for this questionnaire was 0.978, which indicated a relatively high and acceptable reliability $[71,90]$. The questionnaire also proved satisfying in terms of the content validity, criterion-related validity, and construct validity (Table 2, Table 3).

Table 2. Profile of survey respondents $(n=588)$.

\begin{tabular}{ccc}
\hline Variable & $n$ & Percentage \\
\hline Gender & & \\
Male & 260 & $44.22 \%$ \\
Female & 328 & $55.78 \%$ \\
Age & & \\
$25-35$ & 270 & $45.92 \%$ \\
$36-45$ & 122 & $20.75 \%$ \\
$46-55$ & 114 & $19.39 \%$ \\
$56-65$ & 36 & $6.12 \%$ \\
Other & 46 & $7.82 \%$ \\
Educational Level & & \\
Associate's degree & 68 & $11.56 \%$ \\
Bachelor's degree & 300 & $51.02 \%$ \\
Graduate degree & 190 & $32.31 \%$ \\
Other & 30 & $5.10 \%$ \\
Monthly income (US dollar) & & \\
$<500$ & 36 & $6.12 \%$ \\
501-800 & 114 & $19.39 \%$ \\
$801-1200$ & 270 & $45.92 \%$ \\
1201-2000 & 122 & $20.75 \%$ \\
$>2001$ & 46 & $7.82 \%$ \\
Occupation & & \\
Civil servant & 20 & $3.40 \%$ \\
Company employee & 202 & $34.35 \%$ \\
Student & 84 & $14.29 \%$ \\
Professional & 96 & $16.33 \%$ \\
Self-employed & 78 & $13.27 \%$ \\
Other & 108 & $18.37 \%$ \\
\hline & &
\end{tabular}

Table 3. Validity statistics.

\begin{tabular}{cccc}
\hline & & Number & \% \\
\hline \multirow{3}{*}{ Cases } & Valid & 588 & 100 \\
& Excludeda & 0 & 0 \\
& Total & 588 & 100 \\
\hline
\end{tabular}

Cronbach's alpha is a function of the number of test items and the average inter-correlation among the items. It showed the formula of the Cronbach's alpha below [114]:

$$
\alpha=\frac{\mathrm{N} * \overline{\mathrm{C}}}{\overline{\mathrm{v}}+(\mathrm{N}-1) * \overline{\mathrm{C}}} .
$$

Here, $\mathrm{N}$ is equal to the number of items, $\overline{\mathrm{c}}$ is the average covariance between the item-pairs, and $\overline{\mathrm{v}}$ is equal to the average variance. It can be seen from this formula that, if you increase the number of items, you will increase Cronbach's alpha. In addition, if the correlation between the average items is low, the alpha will be low. As the correlation between the average items increases, Cronbach's alpha will increase (keeping the number of items unchanged). 


\subsubsection{Importance-Performance Scores}

The mean responses for the importance and performance of the 30 attributes were analyzed in accordance with the IPA framework and are shown in Table 4. Most of the importance and performance means (Table 5.) were found to be significantly different (Sig. 2-tailed) at the $<0.01$ level (QN. $23 / 25 / 28 / 29 / 30<0.05)$ [117]. Variables in each category were ranked in order by Paired Differences (IA-PB) [118,119].

Table 4. Reliability Statistics.

\begin{tabular}{cc}
\hline Cronbach's Alpha & Number of Items \\
\hline 0.978 & $30 \mathrm{IA}+30 \mathrm{~PB}$ \\
\hline
\end{tabular}

Note: IA = Importance (After COVID-19), PB = Performance (Before COVID-19).

Table 5. Rank, means of importance and performance and paired samples $(n=588)$.

\begin{tabular}{|c|c|c|c|c|c|c|c|c|c|}
\hline \multirow[b]{2}{*}{ QN } & \multicolumn{3}{|c|}{ Paired Differences (IA-PB) } & \multicolumn{2}{|c|}{ IA } & \multicolumn{2}{|c|}{ PB } & \multirow{2}{*}{$\begin{array}{l}\text { Pearson } \\
\text { Correlation }\end{array}$} & \multirow{2}{*}{$\begin{array}{c}\text { Sig. } \\
\text { (2-Tailed) }\end{array}$} \\
\hline & Mean & Rank & Std. Deviation & Mean & Rank & Mean & Rank & & \\
\hline 21 & 0.833 & 1 & 1.342 & 4.020 & 30 & 3.918 & 24 & 0.299 & 0.000 \\
\hline 11 & 0.769 & 2 & 1.271 & 4.510 & 15 & 4.228 & 17 & 0.370 & 0.000 \\
\hline 6 & 0.697 & 3 & 1.114 & 4.595 & 11 & 4.456 & 8 & 0.426 & 0.000 \\
\hline 22 & 0.507 & 4 & 1.196 & 4.197 & 27 & 4.095 & 20 & 0.446 & 0.000 \\
\hline 16 & 0.493 & 5 & 1.037 & 4.449 & 19 & 4.398 & 12 & 0.547 & 0.000 \\
\hline 5 & 0.459 & 6 & 1.043 & 4.374 & 23 & 4.048 & 21 & 0.555 & 0.000 \\
\hline 12 & 0.350 & 7 & 0.827 & 4.731 & 5 & 4.578 & 1 & 0.539 & 0.000 \\
\hline 8 & 0.337 & 8 & 0.922 & 4.442 & 22 & 3.949 & 23 & 0.541 & 0.000 \\
\hline 13 & 0.327 & 9 & 0.871 & 4.102 & 28 & 3.874 & 27 & 0.655 & 0.000 \\
\hline 19 & 0.282 & 10 & 0.845 & 4.558 & 14 & 4.456 & 9 & 0.596 & 0.000 \\
\hline 17 & 0.272 & 11 & 0.805 & 4.592 & 12 & 4.466 & 7 & 0.677 & 0.000 \\
\hline 20 & 0.228 & 12 & 1.057 & 4.463 & 18 & 4.327 & 14 & 0.537 & 0.000 \\
\hline 1 & 0.221 & 13 & 0.740 & 4.650 & 8 & 4.429 & 10 & 0.649 & 0.000 \\
\hline 4 & 0.214 & 14 & 0.728 & 4.765 & 1 & 4.415 & 11 & 0.605 & 0.000 \\
\hline 10 & 0.207 & 15 & 0.696 & 4.306 & 26 & 4.116 & 19 & 0.635 & 0.000 \\
\hline 3 & 0.194 & 16 & 0.665 & 4.561 & 13 & 3.793 & 29 & 0.642 & 0.000 \\
\hline 18 & 0.190 & 17 & 0.741 & 4.446 & 20 & 4.344 & 13 & 0.727 & 0.000 \\
\hline 7 & 0.187 & 18 & 0.682 & 4.704 & 6 & 4.558 & 2 & 0.669 & 0.000 \\
\hline 9 & 0.163 & 19 & 0.686 & 4.476 & 17 & 4.204 & 18 & 0.736 & 0.000 \\
\hline 2 & 0.153 & 20 & 0.634 & 4.738 & 3 & 4.531 & 4 & 0.665 & 0.000 \\
\hline 15 & 0.146 & 21 & 0.662 & 4.371 & 24 & 3.864 & 28 & 0.661 & 0.000 \\
\hline 14 & 0.139 & 22 & 0.684 & 4.446 & 21 & 3.612 & 30 & 0.688 & 0.000 \\
\hline 27 & 0.136 & 23 & 0.780 & 4.599 & 10 & 3.901 & 25 & 0.631 & 0.000 \\
\hline 24 & 0.126 & 24 & 0.762 & 4.082 & 29 & 4.003 & 22 & 0.623 & 0.000 \\
\hline 28 & 0.102 & 25 & 0.891 & 4.701 & 7 & 4.514 & 6 & 0.701 & 0.006 \\
\hline 29 & 0.102 & 26 & 0.722 & 4.633 & 9 & 4.296 & 16 & 0.755 & 0.001 \\
\hline 25 & 0.102 & 27 & 0.717 & 4.738 & 4 & 4.524 & 5 & 0.728 & 0.001 \\
\hline 26 & 0.102 & 28 & 0.678 & 4.340 & 25 & 3.881 & 26 & 0.693 & 0.000 \\
\hline 30 & 0.078 & 29 & 0.773 & 4.483 & 16 & 4.320 & 15 & 0.709 & 0.014 \\
\hline 23 & 0.051 & 30 & 0.711 & 4.738 & 2 & 4.544 & 3 & 0.726 & 0.042 \\
\hline
\end{tabular}

\subsection{Importance (after COVID-19)-Performance (before COVID-19) Analysis (IPA)}

Figure 6 shows results of the analysis. High priority area (part of Quadrant 4+3): (Quadrant 4) the "concentrate here" area; (Quadrant 3) the "low priority" area. The attributes in this quadrant were considered to perform poorly and therefore represent the main weakness of the product and a threat to its competitiveness. In terms of investment, these attributes have the highest priority [98]. Rank by paired differences (IA-PB): (1)“The layout of the rooms is scattered", (2) "Split air conditioners are used in guest rooms", (3) "Places or items for cleaning and disinfection are provided to tourists", (4) "Rooms of Single B\&B are few and exquisite", (5) "Contingency plans are developed and can be exercised regularly", and (6) "Buildings are intelligent (e.g., semi-self-service management)".

Priority area (part of Quadrant 1+3): (Quadrant 1) the "keep up the good work" area; (Quadrant 3) the "low priority" area. It represents the main and potential competitive advantages of a product or service. Attributes in this quadrant are considered to be performing well and investment needs to continue. Rank by paired differences (IA-PB): (7) “Rooms are naturally ventilated", (8) "The emergency 
facilities are complete (such as: first aid kit, escape equipment)", (9) "The rooms are spacious and clean", (10) "The outdoor space is large and natural (e.g., courtyard, terrace, roof garden)", and (11) "Green consumption is encouraged and environmental protection measures are implemented".

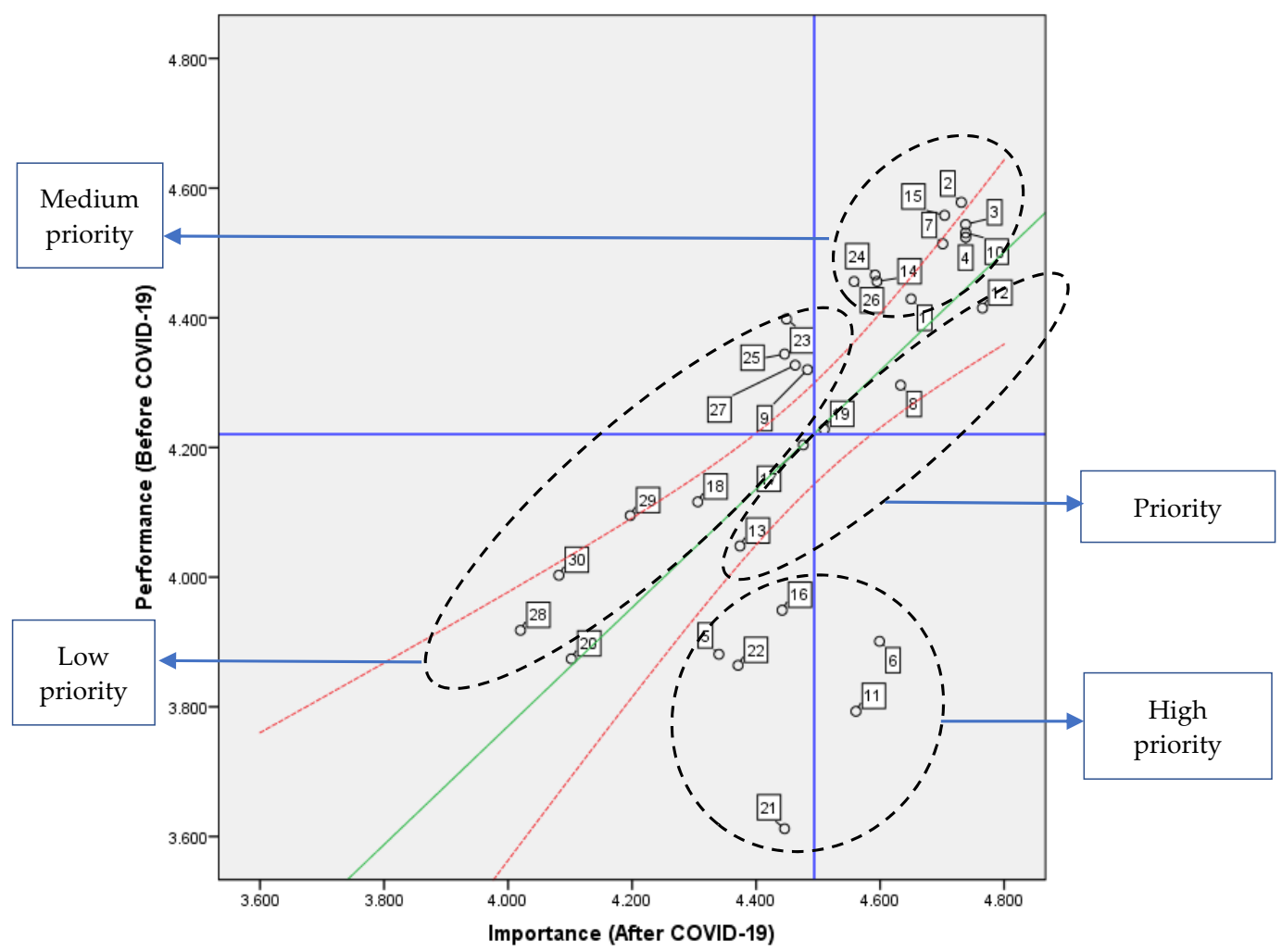

Note:
(1) Data-centered (DC) line
(2) Fit method: Fit line = Linear
(3) Confidence intervals: Mean = Mean of Paired Differences (IA-PB)

Figure 6. The importance (after COVID-19)-performance (before COVID-19) analysis model.

Medium priority area (part of Quadrant 1): (Quadrant 1) the "only keep up the good work" area. The importance and performance of these factors (e.g., "location and nearby facilities are safe and good", "other service rooms are clean and tidy") were good.

Low priority area (part of Quadrant 2+3): (Quadrant 2) the "possible overkill" area; (Quadrant 3) the "low priority" area. Their performance was not particularly good, but they were considered relatively unimportant to tourists; therefore, managers should not pay too much attention to these attributes. They represent a slight weakness, and poor performance is not a big problem. These factors are not important in this article (e.g., "the indoor and outdoor transition spaces are natural and beautiful (e.g., gallery frames, awnings, balconies)", "the shading performance is good (e.g., opaque curtains))".

\section{Discussion}

\subsection{Impacts}

Implications

First, to the best of our knowledge, this study is among the first to uncover the impact of COVID-19 factors influencing tourists' satisfaction with B\&Bs. Second, from the perspective of methodology, DC and IRL were combined with content analysis to sort and guide the complexity of the relationship between variables, which has certain value for future research. Third, some suggestions would be 
given to the B\&B industry to recover after COVID-19 by the importance-performance analysis (IPA). Our study extends this research area from the traditional $B \& B$ context and adds knowledge to the post-COVID-19 B\&B tourism management area.

\subsection{Suggestions}

This study also has practical suggestions for B\&B operators in making marketing strategies after COVID-19. As our results show, psychological factors can directly affect the satisfaction of consumers after Covid-19. The managers of B\&Bs should consider the following factors in the "High priority area" and "Priority area". Compared to before COVID-19, tourists were more concerned with the natural and safe experience associated with B\&Bs after COVID-19. These are some suggestions to improve consumption experience.

\subsubsection{High Priority Suggestions}

Suggestions for the rank by paired differences (IA-PB): (1) "The layout of the rooms is scattered". This shows that, after the COVID-19 epidemic, tourists prefer scattered room layouts. Centralized room layouts need to be reconsidered. (2) "Split air conditioners are used in guest rooms". At present, central air conditioning has been used by many B\&Bs. However, after COVID-19, this is not an ideal choice. (3) "Places or items for cleaning and disinfection are provided to tourists", and (4) "Rooms of Single B\&B are few and exquisite". At present, there are more and more rooms in many B\&Bs (single) and the scale is getting larger. This is obviously inappropriate for B\&B tourism after the COVID-19 epidemic and it needs to be changed. (5) "Contingency plans are developed and can be exercised regularly". These measures were not paid enough attention before the outbreak. It needs to be focused on after the COVID-19 epidemic. (6) "Buildings are intelligent (e.g., semi-self-service management)". "Intelligentization" will be a trend in the future. It also needs to be focused on in B\&Bs.

\subsubsection{Priority Suggestions}

Suggestions for the rank by paired differences (IA-PB): (7) "Rooms are naturally ventilated", (8) "The emergency facilities are complete (such as first aid kit, escape equipment)", (9) "The rooms are spacious and clean", (10) "The outdoor space is large and natural (e.g., courtyard, terrace, roof garden)", and (11) "Green consumption is encouraged and environmental protection measures are implemented". The suggestion in this part is that more attention should be paid to nature and green areas in the B\&B tourism after COVID-19. Just like after SARS in 2003, people tended to go to places with nature-based areas rather than urban vacations [7,43].

\section{Conclusions}

The priority suggestions in this paper will be of great help to improve the attraction of B\&Bs to tourists after Covid-19. Enough attention was not paid to these measures before the outbreak. They need to be focused on after the COVID-19 epidemic. B\&Bs are very important for the tourism industry in many countries, and tourists have especially welcomed them in recent years in China. To the best of our knowledge, our study was among the first to investigate the immediate impact of the COVID-19 pandemic on tourist satisfaction with B\&Bs in China. Many previous studies have reported on COVID-19. Some others studied the correlations between COVID-19 and the quality of life in China. However, few studies have reported the impact of B\&B under COVID-19 on tourism in China. The adjusted importance (after COVID-19)-performance (before COVID-19) analysis (IPA) was a new attempt. Moreover, some promotion suggestions were given to the $B \& B$ industry recovery after COVID-19 by the IPA.

However, there were some limitations to our study and future research areas. First, the data were collected from tourists in B\&Bs in Zhejiang, China. Thus, it was somewhat difficult to apply the suggestions of the impact of COVID-19 to other areas. Future researchers may expand this scope. Second, although we identified the relationships between the determinants of tourist satisfaction and 
COVID-19, the relative strength of these correlations was unknown. We can test the model and identify the degree of influence of the correlations between these factors to promote the $B \& B$ industry in further research. More nuanced research questions should be incorporated. Third, the current paper employed an IPA approach. Even though this method is a widely known method in the tourism industry, it was also a new attempt to use the IPA model with B\&Bs. Thus, we suggest that researchers in other parts of China and in other continents work together to produce similar studies, thereby creating a worldwide body of literature that examines the phenomena related to the effects of crises (e.g., COVID-19) and their impact on B\&Bs and tourism.

Author Contributions: Conceptualization, Y.H. and G.C.; data curation, Y.H. and G.C.; formal analysis, Y.H. and G.C.; funding acquisition, Y.H., G.C., Z.M. and W.G.; investigation, Y.H., G.C., J.J. and Y.J.; methodology, Y.H. and G.C.; project administration, Y.H. and G.C.; resources, Y.H., G.C. and Y.J.; software, G.C. and Y.J.; supervision, Y.H., G.C., Z.M. and W.G.; validation, Y.H., G.C. and W.G.; visualization, Y.H., Z.M. and L.X.; writing-original draft, Y.H. and G.C.; writing-review and editing, Y.H. and G.C. All authors have read and agreed to the published version of the manuscript.

Funding: This research was funded and supported by the Key Technologies Research and Development Program, grant number 2018YFE0106100; the National Social Science Fund of China, grant number 19BSH060; Zhejiang Provincial Key R\&D Program, grant number 2019C02031; National Natural Science Foundation of China, grant number 51878592.

Conflicts of Interest: The authors declare no conflict of interest.

\section{Appendix A}

The sample questionnaire.

\begin{tabular}{|c|c|c|c|c|c|c|c|c|c|c|c|c|}
\hline \multicolumn{2}{|l|}{ Do you have experienced B\&B in Zhejiang before the COVID-19? } & \multirow{2}{*}{\multicolumn{5}{|c|}{ 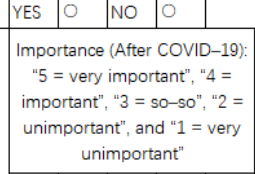 }} & \multirow{2}{*}{\multicolumn{6}{|c|}{$\begin{array}{l}\text { Performance (Before COVID- } \\
\text { 19): "5 = very good", " } 4= \\
\text { good", " } 3=\text { so-so", " } 2=\text { not } \\
\text { good", and "1 = bad". }\end{array}$}} \\
\hline \multirow[t]{2}{*}{$\begin{array}{l}30 \text { factors: performance (before COVID-19)/importance (after COVID-19) } \\
\text { Note: QN = Question Number }\end{array}$} & \multirow[t]{2}{*}{ QN } & & & & & & & & & & & \\
\hline & & & & & & 5 & & & & & & \\
\hline Location and nearby facilities are safe \& good. & 1 & 0 & 0 & 0 & 0 & 0 & 0 & 0 & 0 & 0 & 0 & \\
\hline Other service rooms are clean and tidy. & 4 & 0 & O & 0 & O & O & 0 & O & O & 0 & O & \\
\hline Buildings are intelligent (e.g. semi-self-service management). & 5 & 0 & O & 0 & O & 0 & 0 & o & 0 & 0 & 0 & \\
\hline Places or items for cleaning and disinfection are provided to tourists. & 6 & 0 & O & 0 & O & O & 0 & 0 & O & 0 & O & \\
\hline The building is safe and reliable. & 7 & 0 & 0 & 0 & 0 & 0 & 0 & 0 & 0 & 0 & 0 & \\
\hline The emergency facilities are complete (such as: first aid kit, escape equipment). & 8 & 0 & O & 0 & O & O & 0 & O & O & O & O & \\
\hline The shading performance is good (e.g. opaque curtains). & 9 & 0 & 0 & 0 & 0 & 0 & 0 & 0 & 0 & 0 & 0 & \\
\hline The privacy of rooms is good. & 15 & 0 & 0 & 0 & 0 & 0 & 0 & O & O & 0 & 0 & \\
\hline Contingency plans are developed and can be exercised regularly. & 16 & 0 & O & 0 & O & O & 0 & O & 0 & o & 0 & \\
\hline Green consumption is encouraged and environmental protection measures are implemented. & 17 & 0 & 0 & 0 & O & 0 & 0 & 0 & 0 & 0 & 0 & \\
\hline The indoor and outdoor transition spaces are natural and beautiful (e.g. gallery frames, awnings, balconies). & 18 & 0 & 0 & 0 & O & 0 & 0 & 0 & 0 & 0 & 0 & \\
\hline The outdoor space is large and natural (e.g. courtyard, terrace, roof garden). & 19 & 0 & 0 & 0 & O & O & 0 & 0 & O & O & O & \\
\hline The proportion of public space is large. & 20 & 0 & 0 & 0 & 0 & 0 & 0 & o & 0 & 0 & 0 & \\
\hline The layout of the rooms is scattered. & 21 & 0 & 0 & 0 & O & 0 & 0 & 0 & O & O & 0 & \\
\hline Rooms of Single B\&B are few and exquisite. & 22 & 0 & 0 & 0 & 0 & 0 & 0 & 0 & 0 & 0 & 0 & \\
\hline The local culture is attractive. & 23 & 0 & 0 & 0 & O & 0 & 0 & 0 & O & 0 & 0 & \\
\hline The local people around the B \& B are kind. & 24 & 0 & 0 & o & O & 0 & 0 & 0 & 0 & o & 0 & \\
\hline The environment around the $B$ \& $B$ is rural and natural. & 25 & 0 & 0 & 0 & 0 & 0 & 0 & 0 & 0 & 0 & 0 & \\
\hline The B \& B atmosphere is good (e.g. leisurely, warm). & 26 & 0 & 0 & 0 & o & 0 & 0 & 0 & 0 & 0 & 0 & \\
\hline
\end{tabular}




\section{References}

1. Singhal, T. A review of coronavirus disease-2019 (COVID-19). Indian J. Pediatr. 2020, 1-6. [CrossRef] [PubMed]

2. Spagnuolo, G.; De Vito, D.; Rengo, S.; Tatullo, M. COVID-19 Outbreak: An Overview on Dentistry. Int. J. Environ. Res. Public Health 2020, 17, 2094. [CrossRef]

3. Lu, H.; Stratton, C.W.; Tang, Y.W. Outbreak of pneumonia of unknown etiology in Wuhan, China: The mystery and the miracle. J. Med. Virol. 2020, 92, 401-402. [CrossRef]

4. Wu, Z.; McGoogan, J.M. Characteristics of and Important Lessons from the Coronavirus Disease 2019 (COVID-19) Outbreak in China: Summary of a Report of 72314 Cases from the Chinese Center for Disease Control and Prevention. JAMA J. Am. Med. Assoc. 2020, 323, 1239-1242. [CrossRef] [PubMed]

5. Meltzer, M.I.; Cox, N.J.; Fukuda, K. The economic impact of pandemic influenza in the United States: Priorities for intervention. Emerg. Infect. Dis. 1999, 5, 659. [CrossRef] [PubMed]

6. Bloomberg Businessweek, Coronavirus Is More Dangerous for the Global Economy Than SARS. Available online: https://www.bloomberg.com/news/articles/2020-01-31/the-coronavirus-is-more-dangerous-for-theeconomy-than-sars (accessed on 1 May 2020).

7. Wang, J.; Wang, Z. Strengths, Weaknesses, Opportunities and Threats (SWOT) Analysis of China's Prevention and Control Strategy for the COVID-19 Epidemic. Int. J. Environ. Res. Public Health 2020, 17, 2235. [CrossRef] [PubMed]

8. Work Resumption in China Raises Hope for Virus-Hit European Economies. Available online: https://www.thestar.com.my/news/regional/2020/03/15/work-resumption-in-china-raises-hope-forvirus-hit-european-economies (accessed on 1 May 2020).

9. Mouchtouri, V.; Christoforidou, E.P.; Der Heiden, A.; Lemos, C.M.; Fanos, M.; Rexroth, U.; Grote, U.; Belfroid, E.; Swaan, C.M.; Hadjichristodoulou, C.S.; et al. Exit and Entry Screening Practices for Infectious Diseases among Travelers at Points of Entry: Looking for Evidence on Public Health Impact. Int. J. Environ. Res. Public Health 2019, 16, 4638. [CrossRef]

10. Han, H.; Yu, J.; Hyun, S.S. Nature based solutions and customer retention strategy: Eliciting customer well-being experiences and self-rated mental health. Int. J. Hosp. Manag. 2020, 86, 102446. [CrossRef]

11. Sun, Z.; Thilakavathy, K.; Kumar, S.; He, G.; Liu, S. Potential Factors Influencing Repeated SARS Outbreaks in China. Int. J. Environ. Res. Public Health 2020, 17, 1633. [CrossRef]

12. Zeng, B.; Carter, R.; De Lacy, T. Short-term Perturbations and Tourism Effects: The Case of SARS in China. Curr. Issues Tour. 2005, 8, 306-322. [CrossRef]

13. Xinhuanet. Zhejiang's Resumption of Production and Production Started the "Robbery War". Available online: http://www.xinhuanet.com/politics/2020-02/20/c_1125598806.htm (accessed on 1 May 2020).

14. Chinadaily.com.cn. Research Report on the Development of China B\&B Industry in the First Half of 2019. Available online: https://caijing.chinadaily.com.cn/a/201910/24/WS5db16cbca31099ab995e7a64.html (accessed on 1 May 2020).

15. Li, S.; Wang, Y.; Xue, J.; Zhao, N.; Zhu, T. The Impact of COVID-19 Epidemic Declaration on Psychological Consequences: A Study on Active Weibo Users. Int. J. Environ. Res. Public Health 2020, 17, 2032. [CrossRef]

16. Zhang, Y.; Ma, Z.F. Impact of the COVID-19 Pandemic on Mental Health and Quality of Life among Local Residents in Liaoning Province, China: A Cross-Sectional Study. Int. J. Environ. Res. Public Health 2020, 17, 2381. [CrossRef] [PubMed]

17. Jones, D.L.; Guan, J.J. Bed and Breakfast Lodging Development in Mainland China: Who is the Potential Customer? Asia Pac. J. Tour. Res. 2011, 16, 517-536. [CrossRef]

18. Ye, S.; Xiao, H.; Lingqiang, Z. Small accommodation business growth in rural areas: Effects on guest experience and financial performance. Int. J. Hosp. Manag. 2019, 76, 29-38. [CrossRef]

19. Hussain, A.; Sial, M.S.; Usman, S.M.; Hwang, J.; Jiang, Y.; Shafiq, A. What Factors Affect Patient Satisfaction in Public Sector Hospitals: Evidence from an Emerging Economy. Int. J. Environ. Res. Public Health 2019, 16, 994. [CrossRef]

20. Kanwel, S.; Lingqiang, Z.; Asif, M.; Hwang, J.; Hussain, A.; Jameel, A. The Influence of Destination Image on Tourist Loyalty and Intention to Visit: Testing a Multiple Mediation Approach. Sustainability 2019, 11, 6401. [CrossRef]

21. Martilla, J.A.; James, J.C. Importance-Performance Analysis. J. Mark. 1977, 41, 77-79. [CrossRef] 
22. Sever, I. Importance-performance analysis: A valid management tool? Tour. Manag. 2015, 48, 43-53. [CrossRef]

23. Mair, J.; Ritchie, B.W.; Walters, G. Towards a research agenda for post-disaster and post-crisis recovery strategies for tourist destinations: A narrative review. Curr. Issues Tour. 2014, 19, 1-26. [CrossRef]

24. Giupponi, G.; Innamorati, M.; Rogante, E.; Sarubbi, S.; Erbuto, D.; Maniscalco, I.; Sanna, L.; Conca, A.; Lester, D.; Pompili, M. The Characteristics of Mood Polarity, Temperament, and Suicide Risk in Adult ADHD. Int. J. Environ. Res. Public Health 2020, 17, 2871. [CrossRef]

25. Serafini, G.; Parisi, V.; Aguglia, A.; Amerio, A.; Sampogna, G.; Fiorillo, A.; Pompili, M.; Amore, M. A Specific Inflammatory Profile Underlying Suicide Risk? Systematic Review of the Main Literature Findings. Int. J. Environ. Res. Public Health 2020, 17, 2393. [CrossRef] [PubMed]

26. Napoli, A.; Lamis, D.A.; Berardelli, I.; Canzonetta, V.; Sarubbi, S.; Rogante, E.; Napoli, P.-L.; Serafini, G.; Erbuto, D.; Tambelli, R.; et al. Anxiety, Prenatal Attachment, and Depressive Symptoms in Women with Diabetes in Pregnancy. Int. J. Environ. Res. Public Health 2020, 17, 425. [CrossRef] [PubMed]

27. Michael Hall, C. Crisis events in tourism: Subjects of crisis in tourism. Curr. Issues Tour. 2010, 13, $401-417$. [CrossRef]

28. Wilder-Smith, A. Tourism and SARS; Elsevier Ltd.: Amsterdam, The Netherlands, 2006; ISBN 0080446663.

29. Fakeye, P.C.; Crompton, J.L. Image Differences between Prospective, First-Time, and Repeat Visitors to the Lower Rio Grande Valley. J. Travel Res. 1991, 30, 10-16. [CrossRef]

30. Paunovic, I. Satisfaction of tourists in Serbia, destination image, loyalty and DMO service quality. Eur. J. Tour. Hosp. Recreat. 2014, 5, 163-181.

31. Paunović, I. Proposal for Serbian Tourism Destinations Marketing Campaign/Predlog Za Marketinšku Kampanju Srpskih Turističkih Destinacija. Eur. J. Appl. Econ. 2013, 10, 40-52. [CrossRef]

32. Han, H.; Lee, S.; Hyun, S.S. Role of Internal and External Museum Environment in Increasing Visitors' Cognitive/Affective/Healthy Experiences and Loyalty. Int. J. Environ. Res. Public Health 2019, 16, 4537. [CrossRef]

33. Paunović, I.; Jovanovic, V. Sustainable mountain tourism in word and deed: A comparative analysis in the macro regions of the Alps and the Dinarides. Acta Geogr. Slov. 2019, 59. [CrossRef]

34. Paunovic, I.; Jovanovic, V. Implementation of Sustainable Tourism in the German Alps: A Case Study. Sustainability 2017, 9, 226. [CrossRef]

35. Lee, C.-K.; Lee, Y.-K.; Lee, B. Korea's destination image formed by the 2002 World Cup. Ann. Tour. Res. 2005, 32, 839-858. [CrossRef]

36. Gartner, W.C. Image Formation Process. J. Travel Tour. Mark. 1994, 2, 191-216. [CrossRef]

37. Wang, J.; Ritchie, B.W. A theoretical model for strategic crisis planning: Factors influencing crisis planning in the hotel industry. Int. J. Tour. Policy 2010, 3, 297-317. [CrossRef]

38. Ritchie, B. Tourism disaster planning and management: From response and recovery to reduction and readiness. Curr. Issues Tour. 2008, 11, 315-348. [CrossRef]

39. Cai, G.; Wang, J.; Xu, L.; Gao, W. Observations of Chinese City Architecture Biennale Driven by Economy. J. Asian Inst. Low Carbon Des. 2020, 01, 71-76.

40. Cai, G.; Xu, L.; Gao, W.; Zhang, Y. A Review of the Studies on the China Architecture Exhibition. J. Asian Inst. Low Carbon Des. 2020, 01, 97-102.

41. Nuntsu, N.; Tassiopoulos, D.; Haydam, N. The bed and breakfast market of Buffalo City (BC), South Africa: Present status, constraints and success factors. Tour. Manag. 2004, 25, 515-522. [CrossRef]

42. Lynch, P.A. The commercial home enterprise and host: A United Kingdom perspective. Int. J. Hosp. Manag. 2005, 24, 533-553. [CrossRef]

43. Xiao, L.; Mi, C.; Chen, Y.; Huang, L. Understanding the determinants of consumer satisfaction with B\&B hotels: An interpretive structural modeling approach. Int. J. Web Serv. Res. 2019, 16, 21-39.

44. Chen, L.-C.; Lin, S.-P.; Kuo, C.-M. Rural tourism: Marketing strategies for the bed and breakfast industry in Taiwan. Int. J. Hosp. Manag. 2013, 32, 278-286. [CrossRef]

45. Chiu, C.-N. How can managerial efficiency be improved? Evidence from the bed and breakfast industry. Tour. Manag. Perspect. 2018, 27, 111-124.

46. Hsieh, Y.-C.J.; Lin, Y.-H.P. Bed and Breakfast operators' work and personal life balance: A cross-cultural comparison. Int. J. Hosp. Manag. 2010, 29, 576-581. [CrossRef] 
47. Yang, R. Research on the B\&B (Bed and Breakfast) Market Network Attention in China Based on Baidu Index. In Proceedings of the 2019 2nd International Workshop on Advances in Social Sciences (IWASS 2019), London, UK, 28-30 November 2019; Volume 2, pp. 37-44.

48. Kozak, M.; Bigne, E.; Andreu, L. Limitations of Cross-Cultural Customer Satisfaction Research and Recommending Alternative Methods. J. Qual. Assur. Hosp. Tour. 2004, 4, 37-59. [CrossRef]

49. Forte, A.; Trobia, F.; Gualtieri, F.; Lamis, D.A.; Cardamone, G.; Giallonardo, V.; Fiorillo, A.; Girardi, P.; Pompili, M. Suicide Risk among Immigrants and Ethnic Minorities: A Literature Overview. Int. J. Environ. Res. Public Health 2018, 15, 1438. [CrossRef] [PubMed]

50. Hau, T.C.; Omar, K. The Impact of Service Quality on Tourist Satisfaction: The Case Study of Rantau Abang Beach as a Turtle Sanctuary Destination. Mediterr. J. Soc. Sci. 2014, 5, 1827. [CrossRef]

51. Berardelli, I.; Sarubbi, S.; Lamis, D.A.; Rogante, E.; Canzonetta, V.; Negro, A.; Guglielmetti, M.; Sparagna, A.; De Angelis, V.; Erbuto, D.; et al. Job Satisfaction Mediates the Association between Perceived Disability and Work Productivity in Migraine Headache Patients. Int. J. Environ. Res. Public Health 2019, 16, 3341. [CrossRef]

52. Kozak, M.; Rimmington, M. Tourist Satisfaction with Mallorca, Spain, as an Off-Season Holiday Destination. J. Travel Res. 2000, 38, 260-269. [CrossRef]

53. Agyeiwaah, E.; Adongo, R.; Dimache, A.O.; Wondirad, A.N. Make a customer, not a sale: Tourist satisfaction in Hong Kong. Tour. Manag. 2016, 57, 68-79. [CrossRef]

54. Chen, C.-F.; Chen, F.-S. Experience quality, perceived value, satisfaction and behavioral intentions for heritage tourists. Tour. Manag. 2010, 31, 29-35. [CrossRef]

55. Cai, G.; Xu, L.; Gao, W.; Hong, Y.; Ying, X.; Wang, Y.; Qian, F. The Positive Impacts of Exhibition-Driven Tourism on Sustainable Tourism, Economics, and Population: The Case of the Echigo-Tsumari Art Triennale in Japan. Int. J. Environ. Res. Public Health 2020, 17, 1489. [CrossRef]

56. Nam, M.; Kim, I.; Hwang, J. Can Local People Help Enhance Tourists' Destination Loyalty? A Relational Perspective. J. Travel Tour. Mark. 2016, 33, 702-716. [CrossRef]

57. Kalwar, S.; Sahito, N.; Memon, I.; Hwang, J.; Mangi, M.Y.; Lashari, Z.A. National Planning Strategies for Agro-based Industrial Development in Secondary Cities of Sindh Province, Pakistan. Sustainability 2019, 11, 7066. [CrossRef]

58. Hwang, J.; Kim, H. Consequences of a green image of drone food delivery services: The moderating role of gender and age. Bus. Strat. Environ. 2019, 28, 872-884. [CrossRef]

59. Hyun, S.S.; Perdue, R.R. Understanding the dimensions of customer relationships in the hotel and restaurant industries. Int. J. Hosp. Manag. 2017, 64, 73-84. [CrossRef]

60. Hyun, S.S.; Kim, W.; Lee, M.J. The impact of advertising on patrons' emotional responses, perceived value, and behavioral intentions in the chain restaurant industry: The moderating role of advertising-induced arousal. Int. J. Hosp. Manag. 2011, 30, 689-700. [CrossRef]

61. Hyun, S.S.; Kang, J. A better investment in luxury restaurants: Environmental or non-environmental cues? Int. J. Hosp. Manag. 2014, 39, 57-70. [CrossRef]

62. Hyun, S.S. Creating a model of customer equity for chain restaurant brand formation. Int. J. Hosp. Manag. 2009, 28, 529-539. [CrossRef]

63. Choi, T.Y.; Chu, R. Determinants of hotel guests' satisfaction and repeat patronage in the Hong Kong hotel industry. Int. J. Hosp. Manag. 2001, 20, 277-297. [CrossRef]

64. Lee, K.-H.; Hyun, S.S.; Park, H.; Kim, K. The Antecedents and Consequences of Psychological Safety in Airline Firms: Focusing on High-Quality Interpersonal Relationships. Int. J. Environ. Res. Public Health 2020, 17, 2187. [CrossRef]

65. Deng, W.; Yeh, M.; Sung, M. A customer satisfaction index model for international tourist hotels: Integrating consumption emotions into the American Customer Satisfaction Index. Int. J. Hosp. Manag. 2013, 35, $133-140$. [CrossRef]

66. Kim, W.G.; Ma, X.; Kim, D.J. Determinants of Chinese hotel customers' e-satisfaction and purchase intentions. Tour. Manag. 2006, 27, 890-900. [CrossRef]

67. Chen, J.-L. The Impact of Bed and Breakfast Atmosphere, Customer Experience, and Customer Value on Customer Voluntary Performance: A Survey in Taiwan. Asia Pac. J. Tour. Res. 2014, 20, 541-562. [CrossRef]

68. Hwang, J.; Han, H.; Choo, S.-W. A strategy for the development of the private country club: Focusing on brand prestige. Int. J. Contemp. Hosp. Manag. 2015, 27, 1927-1948. [CrossRef] 
69. Hwang, J.; Lee, J. (Jay) Understanding customer-customer rapport in a senior group package context. Int. J. Contemp. Hosp. Manag. 2019, 31, 2187-2204. [CrossRef]

70. Hwang, J.; Cho, S.-B.; Kim, W. Philanthropic corporate social responsibility, consumer attitudes, brand preference, and customer citizenship behavior: Older adult employment as a moderator. Soc. Behav. Pers. Int. J. 2019, 47, 1-10. [CrossRef]

71. Wang, G.-L.; Liu, C.-C.; Tseng, S.-R. An evaluation of Taiwanese B\&B service quality using the IPA model. J. Bus. Res. Turk 2012, 4, 20-27.

72. Dressler, M.; Paunovic, I. An exploration of digital innovation activity of German wineries in the regional tourism context: Differentiation and complementarity. In Proceedings of the 1st International Research Workshop on Wine Tourism: Challenges and Futures Perspectives, Strasbourg, France, 27-28 June 2019.

73. Dressler, M. Strategic profiling and the value of wine \& tourism initiatives. Int. J. Wine Bus. Res. 2017, 29, 484-502. [CrossRef]

74. Åke Nilsson, P. Staying on farms: An ideological background. Ann. Tour. Res. 2002, 29, 7-24. [CrossRef]

75. Oh, H.; Fiore, A.M.; Jeoung, M. Measuring Experience Economy Concepts: Tourism Applications. J. Travel Res. 2007, 46, 119-132. [CrossRef]

76. Deng, Y.T.; Lee, H. Exploring the dimensions of bed and breakfast (B\&B) visitors' experiences. Int. J. Tour. Sci. 2019, 19, 166-180. [CrossRef]

77. Chen, Y.; Xiao, L.; Mi, C. Opinion mining from online reviews: Consumer satisfaction analysis with B\&B hotels. In Proceedings of the Pacific Asia Conference on Information Systems (PACIS), Langkawi, Malaysia, 19 July 2017; pp. 1-14.

78. Lyu, S.O.; Hwang, J. Are the days of tourist information centers gone? Effects of the ubiquitous information environment. Tour. Manag. 2015, 48, 54-63. [CrossRef]

79. Hwang, J.; Han, H.; Hyun, S.S. The antecedents and consequences of visitors' participation in a private country club community: The moderating role of extraversion. J. Destin. Mark. Manag. 2018, 7, 89-100. [CrossRef]

80. Parasuraman, A.; Zeithaml, V.A.; Berry, L.L. SERQUAL: A Multiple-Item scale for Measuring Consumer Perceptions of Service Quality. J. Retail. 1988, 64, 12.

81. Han, H.; Chua, B.-L.; Hyun, S.S. Eliciting customers' waste reduction and water saving behaviors at a hotel. Int. J. Hosp. Manag. 2020, 87, 102386. [CrossRef]

82. Han, H.; Hyun, S.S. What influences water conservation and towel reuse practices of hotel guests? Tour. Manag. 2018, 64, 87-97. [CrossRef]

83. Kimes, S.E.; Fitzsimmons, J.A. Selecting Profitable Hotel Sites at La Quinta Motor Inns. Interfaces 1990, 20, 12-20. [CrossRef]

84. Havlena, W.J.; Holbrook, M.B. The Varieties of Consumption Experience: Comparing Two Typologies of Emotion in Consumer Behavior. J. Consum. Res. 1986, 13, 394-404. [CrossRef]

85. Hyun, S.S.; Han, H. Luxury cruise travelers: Other customer perceptions. J. Travel Res. 2015, 54, $107-121$. [CrossRef]

86. Syaqirah, Z.N.; Faizurrahman, Z.P. Managing Customer Retention of Hotel Industry in Malaysia. Procedia Soc. Behav. Sci. 2014, 130, 379-389. [CrossRef]

87. Zeithaml, V.A. Consumer Perceptions of Price, Quality, and Value: A Means-End Model and Synthesis of Evidence. J. Mark. 1988, 52, 2-22. [CrossRef]

88. Oliver, R.L. Satisfaction: A Behavioral Perspective on the Consumer: A Behavioral Perspective on the Consumer, 2nd ed.; Routledge: London, UK, 2014; ISBN 1317460227.

89. Lee, S.; Park, H.; Ahn, Y. The Influence of Tourists' Experience of Quality of Street Foods on Destination's Image, Life Satisfaction, and Word of Mouth: The Moderating Impact of Food Neophobia. Int. J. Environ. Res. Public Health 2019, 17, 163. [CrossRef]

90. Jin, Y.; Park, Y. An Integrated Approach to Determining Rural Tourist Satisfaction Factors Using the IPA and Conjoint Analysis. Int. J. Environ. Res. Public Health 2019, 16, 3848. [CrossRef] [PubMed]

91. Tang, C.; Zheng, Q.; Ng, P. A Study on the Coordinative Green Development of Tourist Experience and Commercialization of Tourism at Cultural Heritage Sites. Sustainability 2019, 11, 4732. [CrossRef]

92. Hwang, J.; Lee, J. (Jay) Relationships among Senior Tourists' Perceptions of Tour Guides' Professional Competencies, Rapport, Satisfaction with the Guide Service, Tour Satisfaction, and Word of Mouth. J. Travel Res. 2018, 58, 1331-1346. [CrossRef] 
93. Bi, J.W.; Liu, Y.; Fan, Z.P.; Zhang, J. Wisdom of crowds: Conducting importance-performance analysis (IPA) through online reviews. Tour. Manag. 2019, 70, 460-478. [CrossRef]

94. Han, H.; Hwang, J. Growing competition in the healthcare tourism market and customer retention in medical clinics: New and experienced travellers. Curr. Issues Tour. 2015, 21, 680-702. [CrossRef]

95. Nicolas, C.; Kim, J.; Chi, S. Quantifying the dynamic effects of smart city development enablers using structural equation modeling. Sustain. Cities Soc. 2020, 53, 101916. [CrossRef]

96. Popa, I.; Ștefan, S.C. Modeling the Pathways of Knowledge Management Towards Social and Economic Outcomes of Health Organizations. Int. J. Environ. Res. Public Health 2019, 16, 1114. [CrossRef]

97. Hwang, J.; Lee, J. A strategy for enhancing senior tourists' well-being perception: Focusing on the experience economy. J. Travel Tour. Mark. 2018, 36, 314-329. [CrossRef]

98. Dwyer, L.; Cvelbar, L.K.; Edwards, D.; Mihalič, T. Fashioning a destination tourism future: The case of Slovenia. Tour. Manag. 2012, 33, 305-316. [CrossRef]

99. Abalo, J.; Varela, J.; Manzano-Arrondo, V. Importance values for Importance-Performance Analysis: A formula for spreading out values derived from preference rankings. J. Bus. Res. 2007, 60, 115-121. [CrossRef]

100. Matzler, K.; Bailom, F.; Hinterhuber, H.H.; Renzl, B.; Pichler, J. The asymmetric relationship between attribute-level performance and overall customer satisfaction: A reconsideration of the importance-performance analysis. Ind. Mark. Manag. 2004, 33, 271-277. [CrossRef]

101. Oh, H. Revisiting importance-performance analysis. Tour. Manag. 2001, 22, 617-627. [CrossRef]

102. Bacon, D.R. A Comparison of Approaches to Importance-Performance Analysis. Int. J. Mark. Res. 2003, 45, 1-15. [CrossRef]

103. Azzopardi, E.; Nash, R. A critical evaluation of importance-performance analysis. Tour. Manag. 2013, 35, 222-233. [CrossRef]

104. Ziegler, J.; Dearden, P.; Rollins, R. But are tourists satisfied? Importance-performance analysis of the whale shark tourism industry on Isla Holbox, Mexico. Tour. Manag. 2012, 33, 692-701. [CrossRef]

105. Alberty, S.; Mihalik, B.J. The Use of Importance-Performance Analysis as an Evaluative Technique in Adult Education. Eval. Rev. 1989, 13, 33-44. [CrossRef]

106. Guadagnolo, F. The importance-performance analysis: An evaluation and marketing tool. J. Park Recreat. Adm. 1985, 3, 13-22.

107. Hollenhorst, S.J.; Olson, D.; Fortney, R. Use of importance-performance analysis to evaluate state park cabins: The case of the West Virginia state park system. J. Park Recreat. Adm. 1992, 10, 1-11.

108. Lai, I.K.W.; Hitchcock, M. Importance-performance analysis in tourism: A framework for researchers. Tour. Manag. 2015, 48, 242-267. [CrossRef]

109. Arana, J.E.; León, C.J. Correcting for Scale Perception Bias in Tourist Satisfaction Surveys. J. Travel Res. 2013, 52, 772-788. [CrossRef]

110. Rial, A.; Rial, J.; Varela, J.; Real, E. An application of importance-performance analysis (IPA) to the management of sport centres. Manag. Leis. 2008, 13, 179-188. [CrossRef]

111. Matzler, K.; Sauerwein, E.; Heischmidt, K. Importance-performance analysis revisited: The role of the factor structure of customer satisfaction. Serv. Ind. J. 2003, 23, 112-129. [CrossRef]

112. Asif, M.; Qing, M.; Hwang, J.; Shi, H. Ethical leadership, affective commitment, work engagement, and creativity: Testing a multiple mediation approach. Sustainability 2019, 11, 4489. [CrossRef]

113. Asif, M.; Jameel, A.; Hussain, A.; Hwang, J.; Sahito, N. Linking Transformational Leadership with Nurse-Assessed Adverse Patient Outcomes and the Quality of Care: Assessing the Role of Job Satisfaction and Structural Empowerment. Int. J. Environ. Res. Public Health 2019, 16, 2381. [CrossRef] [PubMed]

114. Cronbach, L.J. Coefficient alpha and the internal structure of tests. Psychometrika 1951, 16, 297-334. [CrossRef]

115. Han, H.; Sahito, N.; Nguyen, T.V.T.; Hwang, J.; Asif, M. Exploring the Features of Sustainable Urban Form and the Factors that Provoke Shoppers towards Shopping Malls. Sustainability 2019, 11, 4798. [CrossRef]

116. Asif, M.; Jameel, A.; Sahito, N.; Hwang, J.; Hussain, A.; Manzoor, F. Can Leadership Enhance Patient Satisfaction? Assessing the Role of Administrative and Medical Quality. Int. J. Environ. Res. Public Health 2019, 16, 3212. [CrossRef]

117. Han, H.; Hwang, J.; Lee, M.J.; Kim, J. Word-of-mouth, buying, and sacrifice intentions for eco-cruises: Exploring the function of norm activation and value-attitude-behavior. Tour. Manag. 2019, 70, 430-443. [CrossRef] 
118. Hwang, J.; Han, H. Understanding Other Customer Perceptions in the Private Country Club Industry. Asia Pac. J. Tour. Res. 2014, 20, 875-896. [CrossRef]

119. Han, H.; Hwang, J.; Lee, S. Cognitive, affective, normative, and moral triggers of sustainable intentions among convention-goers. J. Environ. Psychol. 2017, 51,1-13. [CrossRef]

(C) 2020 by the authors. Licensee MDPI, Basel, Switzerland. This article is an open access article distributed under the terms and conditions of the Creative Commons Attribution (CC BY) license (http://creativecommons.org/licenses/by/4.0/). 